\title{
Computers and Growth with Costs of Adjustment: Will the Future Look Like the Past?
}

\author{
Michael T. Kiley* \\ Federal Reserve Board \\ Washington, DC 20551 \\ mkiley@frb.gov \\ 202.452.2448
}

July, 1999

\begin{abstract}
This paper augments the traditional growth accounting framework by including a common specification of investment adjustment costs, and uses the new framework to examine the past and likely future growth in nonfarm business output in the US. The inclusion of adjustment costs can have large effects on the growth-accounting exercise when a new investment good is introduced--such as computers in the last thirty years. The new framework indicates that the contribution of computers to economic growth has been held down by the large adjustment costs required to incorporate a new investment good into the economy's capital stock. Alternative calibrations of the model suggest that these adjustment costs have lowered measured growth in multifactor productivity since 1974 by about $1 / 2$ percentage point--a nontrivial percentage of the productivity slowdown. Combining the adjustments to multifactor productivity and the impact of computers implied by the model with adjustment costs boosts long-run growth in output per hour 3/4 percentage point above the 1974-1991 average.
\end{abstract}

JEL Codes: O4, E2

keywords: computers, productivity

*This research was facilitated by the excellent research assistance of Ojas Desai, Raven Saks, and Betsy Vrankovich. Helpful comments were provided by Steve Oliner, Plutarchos Sakellaris, Karl Whelan, and seminar participants at the Federal Reserve Board. Responsibility for any errors lies solely with the author. The views expressed herein are the author's and do not reflect those of the Federal Reserve Board or its staff. 
"We see the computer age everywhere except in the productivity statistics."

\section{Robert Solow}

"An economy that twenty years ago seemed to have seen its better days, is displaying a remarkable run of economic growth that appears to have its roots in ongoing advances in technology."

Alan Greenspan (1999)

Solow's quip is perhaps the most well-known summary of the puzzling failure of computers to raise growth in productivity through the 1980s. Recent years have witnessed a revival in the view that the productivity payoff of computers has finally arrived--or at least is about to assert itself; Alan Greenspan's optimism is this regard was summarized in his testimony at a Congressional hearing on high-tech industries in the spring of 1999. This paper reconsiders the productive impact of computers, both in recent decades and prospectively, in a new "growth accounting" framework that incorporates investment adjustment costs of the magnitude suggested by a wide range of studies. The results are dramatic, suggesting a reconsideration of the magnitude of the "productivity slowdown" that began in the 1970s and an optimistic view of future growth in output.

The literature on the aggregate productive impact of computers (to date) has largely suggested that computers have had only a marginal impact on aggregate labor productivity (Oliner and Sichel (1994), Sichel (1997, 1999), and Jorgenson and Stiroh (1999)). Some authors have strongly suggested that computers will never contribute significantly to growth in labor productivity. Perhaps the most direct attack on the potential of computers to contribute significantly to growth in labor productivity and hence output is that of Robert Gordon (1998):

...[S]omething is wrong with computers... they pale in comparison with the great inventions earlier this century; ...many activities in the service sector are immune to productivity improvements achieved by computers; ...diminishing returns to [computers] has already set in; and... substantial activity generated by computers has zero or negative productivity.

This paper argues that such a conclusion is premature; computers, at least PCs, are relatively new (PCs only entered the Bureau of Labor Statistics' productivity database in the early 1980s), and 
the adjustment costs of incorporating the new technology into business practice are substantial. Examining the recent investment behavior of the US nonfarm business sector in the context of a dynamic, optimizing model of investment with adjustment costs suggests a future of faster output growth spurred by lower adjustment costs and a higher level of investment in computers. In several calibrations of the model designed to match available data on the total costs of computers, including adjustment costs, the steady-state growth rate of output per hour is about 3/4 percentage point larger--near 1.8 percent per year rather than 1 percent per year--than suggested by standard growth-accounting exercises. This difference is large--implying that output per hour doubles every 39 years rather than every 69 years.

The framework proposed in this paper for measuring the contribution of computerspecific technological change, or for that matter any technological change specific to an investment good, is quite similar to the old "growth accounting" literature that focuses on the growth of inputs--including capital goods--and any residual contribution of technological progress (Solow (1957)). The innovation in the framework is the explicit incorporation of adjustment costs of investment. For an economy near a steady-state growth path, incorporating adjustment costs does not have an important impact on growth accounting--because such adjustment costs are very small. However, if an economy is incurring substantial adjustment costs from high levels of investment in some new investment good, say computers, then production is depressed by these adjustment costs, and typical growth accounting calculations will measure the negative effects of adjustment costs as a slowing of growth in the residual-typically called labor-augmenting technological progress or multifactor productivity.

Applying this insight to the growth of nonfarm business output in the US over the past 25 years generates a striking conclusion. The accounting exercise suggests that adjustment costs generated by the high level of investment in computers since 1974 lowered growth in measured multifactor productivity by about 0.5 percentage point--more than 25 percent of the productivity slowdown. The large adjustment costs stemming from the explosion in computer investment also suggest that the marginal value of computer capital is several times the purchase price--as has been suggested by the recent empirical work of Brynjolfsson and Yang (1998). The high marginal value of computer capital implied by the model with adjustment costs raises the long- 
run contribution of computer capital to a level that is double the value suggested by a growth accounting exercise that ignores adjustment costs.

The next section provides some motivation for the incorporation of adjustment costs in a growth accounting exercise. Section 2 presents the model of "growth accounting" in the presence of investment adjustment costs. Section 3 describes the data and calibrations used in the growth analysis of US nonfarm business output. Section 4 provides results for "short-run" growth accounting exercises, and section 5 provides results for the "long-run" growth accounting exercises. Section 6 considers the plausibility of the calibrations in light of previous research on investment adjustment costs for computers and other types of structures and equipment.

\section{Adjustment Costs}

Solow's (1957) contribution to growth accounting demonstrated how the sources of output growth could be decomposed into a contribution from labor input, capital input, and technological progress under three assumptions: the existence of an aggregate production function in which output depends solely on the levels of capital, labor, and a technology index; competitive output and factor markets (i.e., inputs earn their marginal products); and the availability of data on income shares. This framework has spawned an incredibly large academic and professional literature on measuring the sources of output growth. Two prominent examples of government-sponsored data series that grew from Solow's work are the Bureau of Labor Statistics' annual report on multifactor productivity growth and the Congressional Budget Office's measure of potential output--a primary input into long-run budget projections.

An equally influential literature has focused on the effects of investment adjustment costs on a firm's investment decision, with important contributions from Eisner and Strotz (1963), Lucas (1967), and Hayashi (1982). It is well known that investment--at both the firm and aggregate level--responds to changes in the desired capital stock sluggishly (regardless of whether changes in the desired capital stocks are measured by changes in output and the user cost of capital as developed initially in Jorgenson (1963), or by changes in the ratio of the marginal value of investment to the replacement cost of capital as developed in Tobin (1969)). Investment adjustment costs rationalize this sluggish investment behavior by introducing a friction into the 
investment decision. These costs of adjustment reflect a variety of factors, such as the costs of reorganizing plant layouts to incorporate new machinery, managerial costs stemming from alterations to production plans consistent with the installation of new capital, and other costs associated with the interruption of normal work activity to install (or disinstall) capital. At the aggregate level, aggregate convexities are often mentioned as a possible reason why a rapid expansions of investment is costly. More sophisticated treatments of adjustment costs may appeal to worker training and/or learning-on-the-job as factors generating investment adjustment costs (and perhaps try to specifically model these features). Traditionally, empirical implementation of models with investment adjustment costs have found that such costs are large (Chirinko (1993)), and more recent research continues to find that such costs are a primary factor determining investment dynamics (Hassett and Hubbard (1996), Caballero (1997)).

An examination of the potential growth-accounting impact of such adjustment costs has not previously been explored. This paper considers the effect of adjustment costs on the standard growth accounting exercise and finds these effects are large. To see how this can be the case, it is useful to first consider a formalization of adjustment costs introduced in Lucas (1967), wherein output $(\mathrm{Y})$ is a function of capital $(\mathrm{K})$, hours $(\mathrm{H})$, and investment $(\mathrm{I})$ :

$$
\mathrm{Y}=\mathrm{F}(\mathrm{K}, \mathrm{H}, \mathrm{I}) \text {. }
$$

Investment adjustment costs require that increases in investment lower the productive capacity of the firm (or economy), so that $\mathrm{F}_{\mathrm{I}}<0$. Lucas assumes that the production function is constant returns to scale. Following this assumption, taking logs, and differentiating the production function with respect to time yields an equation for output growth.

$$
\mathrm{dy}=\mathrm{s}_{\mathrm{k}} \mathrm{dk}+\mathrm{s}_{\mathrm{h}} \mathrm{dh}+\left(1-\mathrm{s}_{\mathrm{k}}-\mathrm{s}_{\mathrm{h}}\right) \mathrm{di},
$$

where $s_{\mathrm{i}}$ is the elasticity of output with respect to input $\mathrm{i}$ (i.e., input i's marginal product times the input quantity divided by output) and $s_{k}+s_{h}>1$. This is a familiar equation for output growth; output growth depends on the growth of capital and hours--and on the growth of investment if there are adjustment costs. Typically, the term reflecting investment growth is small, reflecting the low level of investment relative to the capital stock. This justifies the standard practice of ignoring investment in growth accounting.

However, certain situations may generate large adjustment costs and hence large effects 
of investment in the growth accounting decomposition. For example, suppose that the economy begins with a very low stock of capital and must adjust towards its long-run desired capital stock. In this situation, investment growth will be high and adjustment costs large--generating a large impact of including investment in the growth accounting exercise.

The key question then becomes whether the impact of adjustment costs is large enough to affect the results of growth accounting in the US. The growth of computers and peripheral equipment provide one case where adjustment costs may be important. As shown in the table, investment in computers and peripheral equipment has grown at phenomenally high rates since mainframe computers were introduced in the BLS productivity database in the mid-1960s, and the nominal share of investment expenditures for computers in nonfarm business output has quadrupled.

\section{Growth Rate of Investment in Computers and Peripheral Equipment}

$1967-1973$

Average Growth Rate

Memo: Share of Nominal NFB output
0.27
1974-1984

38.64

0.58
$1985-1998$

This high rate of investment growth may imply a important modification of traditional growth accounting because the small share of investment may be offset by the phenomenally high growth rate. The following sections more fully develop the theory and provide the results of several calibrated versions of the model.

\section{Growth Accounting with Adjustment Costs}

A voluminous literature considers the impact of investment adjustment costs on firm behavior by specifying convex costs of adjustment, with important contributions by Eisner and Strotz (1963), Lucas (1967), and Hayashi (1982). Convex adjustment costs deliver extremely tractable specifications of investment behavior and have therefore been applied widely in 
empirical research on investment. ${ }^{1}$ Because of this tractability, the model of "growth accounting" presented in this section and the quantitative exercises performed below will employ a specification in which adjustment costs are convex. A specification with non-convex costs of adjustment would still imply similar adjustments to traditional growth accounting (such as the notion that the purchase price of an investment good does not equal its marginal value at every point in time); however, such a specification would likely be analytically intractable and hence make the effects of adjustment costs on growth less transparent.

Consider an economy in which the representative firm produces output $(\mathrm{Y})$ according to the (net) production function

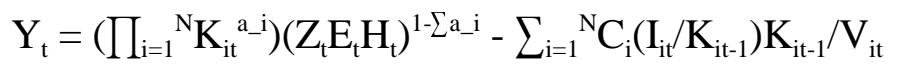

where $\mathrm{N}$ indexes the number of capital assets in the economy, $\mathrm{K}_{\mathrm{r}}$ represents the stock of capital asset i, Z represents labor augmenting technological progress (which is exogenous), E represents labor quality (i.e., human capital, which is exogenous), and $\mathrm{H}$ represents hours of labor input. $\mathrm{C}_{\mathrm{i}}(.) \mathrm{K}_{\mathrm{it}-1}$ is an investment adjustment cost function, and $\mathrm{I}_{\mathrm{i}}$ represents investment in capital asset $\mathrm{i}$. Finally, $\mathrm{V}_{\mathrm{i}}$ is an exogenous index of technological progress in good $\mathrm{i}$ (discussed further below) that alters both the purchase price of the investment good and the costs of adjusting the capital stock of asset i.

The production function (1) differs slightly from that in Lucas (1967) and section 1. First, the production function is constant returns to scale in capital (current), hours, lagged capital, and investment. The incorporation of lagged capital and investment reflects adjustment costs of investment. Second, the production function gross of adjustment costs takes a CobbDouglas form. The Cobb-Douglas form is important for the balanced-growth path derived below (see also Greenwood and Jovanovic (1998)). In addition, adjustment costs in (1) are assumed to be separable across assets, largely for convenience and ease of calibration (as studies of cross-

${ }^{1}$ Of course, alternatives to convex adjustment costs have also received considerable attention, including time-to-build, fixed costs, and irreversibilities. For an introductory treatment of the latter two with references, see Dixit and Pindyck (1994); a more recent summary is provided by Caballero (1997). 
effects of adjustment costs have not been performed). ${ }^{2}$ Adjustment costs for asset i in (1) are also proportional to the inverse of the technology index (V) of asset i, so, for example, technological progress that lowers the price of a computer (and raises $\mathrm{V}$ ) also lowers the adjustment costs associated with computers. This assumption is required for a balanced growth path of the type derived in this section to exist. Adjustment costs are restricted to be convex and of the form $\mathrm{C}_{\mathrm{i}}\left(\mathrm{I}_{\mathrm{it}} / \mathrm{K}_{\mathrm{it}-1}\right) \mathrm{K}_{\mathrm{it}-1}$; these assumptions have been widely used in empirical investigations (following Hayashi (1982)), which will facilitate comparison of the calibrated model to previous work in section 6 .

The representative firm faces competitive output and factor markets, and (for simplicity) a constant nominal interest rate $\mathrm{r}$. The price of final output is denoted by $\mathrm{P}_{\mathrm{t}}$, and inflation is normalized to zero $\left(\mathrm{g}_{\mathrm{p}}=\ln \left(\mathrm{P}_{\mathrm{t}+1} / \mathrm{P}_{\mathrm{t}}\right)=0\right)$. As mentioned above, labor-augmenting technological progress $\left(Z_{t}\right)$ is exogenous; its steady-state growth rate is given by $g_{z}\left(i . e .,\left(\ln \left(Z_{t} / Z_{t-1}\right)=g_{z}\right.\right.$ in the steady state). Similarly, the steady-steady state growth rate of labor quality $\left(\mathrm{E}_{\mathrm{t}}\right)$ is denoted by $\mathrm{g}_{\mathrm{e}}$; the steady-steady state growth rate of labor hours $\left(\mathrm{H}_{\mathrm{t}}\right)$ is denoted by $\mathrm{g}_{\mathrm{h}}$. A final, exogenous source of growth allowed in the model is technological progress that is specific to investment goods $\left(\mathrm{V}_{\mathrm{i}}\right)$; this source of growth lowers the price of investment good i relative to the price of final output, that is, this source of growth is indexed by the (inverse) of the relative price of good $\mathrm{i}\left(\mathrm{V}_{\mathrm{it}}=\mathrm{P}_{\mathrm{t}} / \mathrm{P}_{\mathrm{it}}\right.$, where $\mathrm{P}_{\mathrm{i}}$ is the price of capital asset $\left.\mathrm{i}\right)$. The steady-state growth rate of this index of technological change specific to investment good $\mathrm{i}$ is denoted by $\mathrm{g}_{\mathrm{i}}{ }^{3}$. Note that this

${ }^{2}$ For example, Brynjolfsson and Yang (1998) model and estimate adjustment costs for several capital assets, including computers; their model assumes adjustment costs are separable across assets.

${ }^{3}$ This method of modeling technological progress that is specific to investment goods has recently gained renewed prominence due both to its tractability, and to its direct applicability to hedonic measurement of computer output. The aggregate resource constraint of the economy is given by

$$
\mathrm{P}_{\mathrm{t}} \mathrm{Y}_{\mathrm{t}}=\mathrm{P}_{\mathrm{ct}} \mathrm{C}_{\mathrm{t}}+\sum_{\mathrm{I}=1}{ }^{N} \mathrm{P}_{\mathrm{it}} \mathrm{I}_{\mathrm{it}}
$$

where $P_{c t}$ is the price of the consumption good and $C_{t}$ is the consumption good. (Note: this paper focuses solely on growth accounting and does not consider consumption decisions.) Greenwood and Jovanovic (1998) survey recent work and provide references to other research with similar resource constraints. 
assumption regarding $\mathrm{V}$, combined with aggregate inflation of $\mathrm{g}_{\mathrm{p}}$, implies that the steady-state growth rate of $P_{i}$ is given by $g_{p i}=g_{p}-g_{i}=-g_{i}$.

The firm's costs include wage payments and purchases of capital assets

$$
\text { Total Costs }=\mathrm{W}_{\mathrm{t}} \mathrm{H}_{\mathrm{t}}+\sum_{\mathrm{I}=1}{ }^{\mathrm{N}} \mathrm{P}_{\mathrm{it}} \mathrm{I}_{\mathrm{it}}
$$

where $\mathrm{W}$ is the wage rate. Finally, the firm's stock of capital asset $\mathrm{i}$ evolves according to

$$
\mathrm{K}_{\mathrm{it}}=\left(1-\mathrm{d}_{\mathrm{i}}\right) \mathrm{K}_{\mathrm{it}-1}+\mathrm{I}_{\mathrm{it}}
$$

where $d_{i}$ is the depreciation rate of asset $i$.

The firm maximizes the present discounted value of profits

$$
\begin{gathered}
\sum_{j=0}^{\infty} R^{j}\left\{P_{t+j}\left(\prod_{i=1}{ }^{N} K_{i t+j}{ }^{a}{ }^{-i}\right)\left(Z_{t+j} E_{t+j} H_{t+j}\right)^{1-\sum a_{-} i}-\sum_{i=1}{ }^{N} C_{i}\left(I_{i t+j} / K_{i t+j-1}\right) K_{i t+j-1} / V_{i t+j}\right] \\
\left.-W_{t+j} H_{t+j}-\sum_{i=1}{ }^{N} P_{i t+j} I_{i t+j}\right\}= \\
\sum_{j=0}^{\infty} R^{j}\left\{P_{t+j}\left(\prod_{i=1}{ }^{N} K_{i t+j}{ }^{a}-i\right)\left(Z_{t+j} E_{t+j} H_{t+j}\right)^{1-\sum a-i}-\sum_{i=1}{ }^{N} C_{i}\left(I_{i t+j} / K_{i t+j-1}\right) K_{i t+j-1} P_{i t+j}\right. \\
\left.-W_{t+j} H_{t+j}-\sum_{i=1}{ }^{N} P_{i t+j} I_{i t+j}\right\}
\end{gathered}
$$

where $\mathrm{R}=1 /(1+\mathrm{r})$ and the relationship between technological progress specific to investment good $i$ and the relative price of investment good $i$ has been used (i.e., $V_{i t}=P_{t} / P_{i t}$ ).

The choice variables of the firm are $\mathrm{K}_{\mathrm{i}}, \mathrm{I}_{\mathrm{i}}$, and $\mathrm{H}_{\mathrm{t}}$. The first-order conditions for $\mathrm{K}_{\mathrm{it}}$ and $\mathrm{I}_{\mathrm{it}}$ of the firm maximizing (4) subject to the accumulation constraints (3) $\mathrm{are}^{4}$

$$
\begin{aligned}
& \text { a_i } \left.P_{t} t\left(\prod_{I=1}{ }^{N} K_{i t}{ }_{i t}{ }^{a}\right)\left(Z_{t} E_{t} H_{t}\right)^{1-\sum a \_i}\right] / K_{i t}-R\left\{C_{i}\left(I_{i t+1} / K_{i t}\right) P_{i t+1}-\right. \\
& \left.C_{i}^{\prime}\left(I_{i t+1} / K_{i t}\right) P_{i t+1} I_{i t+1} / K_{i t}\right)=Q_{i t}-R\left(1-d_{i}\right) Q_{i t+1} \\
& C_{i}^{\prime}\left(I_{i t} / K_{i t}\right) P_{i t}+P_{i t}=Q_{i t}
\end{aligned}
$$

where $\mathrm{Q}_{\mathrm{it}}$ is the lagrange multiplier on the constraint (3); note that $\mathrm{Q}_{\mathrm{it}}$ represents the marginal value of asset $i$ which includes both the purchase price and adjustment costs (see (6)). It is useful to rewrite (5) as

$$
\begin{aligned}
& (1+r) a_{-} i P_{t}\left[\left(\prod_{i=1}{ }^{N} K_{i t}{ }_{i t}{ }^{i}\right)\left(Z_{t} E_{t} H_{t}\right)^{1-\sum a_{-} i}\right] / K_{i t}-C_{i}\left(I_{i t+1} / K_{i t}\right) P_{i t+1}+ \\
& C_{i}^{\prime}\left(I_{i t+1} / K_{i t}\right) P_{i t+1} I_{i t+1} / K_{i t}=\left[r+d_{i}-\left(1-d_{i}\right)\left(Q_{i t+1}-Q_{i t}\right) / Q_{i t}\right] Q_{i t}\left(=u_{i t}\right)
\end{aligned}
$$

which equates the marginal product of capital asset $i$ (net of marginal adjustment costs) to the user cost of asset i $\left(\mathrm{u}_{\mathrm{it}}\right)$.

"Short-run Growth Accounting"

\footnotetext{
${ }^{4}$ The first-order condition for $\mathrm{H}$ is standard to growth-accounting exercises without adjustment costs and hence is omitted.
} 
Short-run growth accounting refers to simple differentiation of (1) with respect to time, yielding (to a first-order log-linear approximation with $\mathrm{dx}$ equal to $\mathrm{dln} \mathrm{X} / \mathrm{dt}$ )

$$
\begin{aligned}
\operatorname{dy}(\mathrm{t})= & \left(1-\sum \mathrm{a} \_\mathrm{i}\right)\left[\left(\mathrm{Y}_{\mathrm{t}}+\sum_{\mathrm{I}=1}{ }^{\mathrm{N}} \mathrm{C}_{\mathrm{i}}\left(\mathrm{I}_{\mathrm{it}} / \mathrm{K}_{\mathrm{it}-1}\right) \mathrm{K}_{\mathrm{it}-1} / \mathrm{V}_{\mathrm{it}}\right) / \mathrm{Y}_{\mathrm{t}}\right](\mathrm{dz}(\mathrm{t})+\mathrm{de}(\mathrm{t})+\mathrm{dh}(\mathrm{t}))+ \\
& \sum\left\{\left[\mathrm{a} \_\mathrm{i}\left(\mathrm{Y}_{\mathrm{t}}+\sum_{\mathrm{I}=1}{ }^{\mathrm{N}} \mathrm{C}_{\mathrm{i}}\left(\mathrm{I}_{\mathrm{it}} / \mathrm{K}_{\mathrm{it}-1}\right) \mathrm{K}_{\mathrm{it}-1} / \mathrm{V}_{\mathrm{it}}\right) / \mathrm{Y}_{\mathrm{t}}\right] \mathrm{dk}_{\mathrm{i}}(\mathrm{t})\right\}- \\
& \sum\left\{\left[\left(\mathrm{C}_{\mathrm{i}}^{\prime}\left(\mathrm{I}_{\mathrm{it}} / \mathrm{K}_{\mathrm{it}-1}\right) \mathrm{I}_{\mathrm{it}} / \mathrm{V}_{\mathrm{it}}\right) / \mathrm{Y}_{\mathrm{t}}\right] \mathrm{di} \mathrm{i}_{\mathrm{i}}(\mathrm{t})\right\}+\sum\left\{\left[\left(\mathrm{C}_{\mathrm{i}}\left(\mathrm{I}_{\mathrm{it}} / \mathrm{K}_{\mathrm{it}-1}\right) \mathrm{K}_{\mathrm{it}-1} / \mathrm{V}_{\mathrm{it}}\right) / \mathrm{Y}_{\mathrm{t}}\right] \mathrm{dv}_{\mathrm{i}}(\mathrm{t})\right\}- \\
& \sum\left\{\left[\left(\mathrm{C}_{\mathrm{i}}\left(\mathrm{I}_{\mathrm{it}} / \mathrm{K}_{\mathrm{it}-\mathrm{t}}\right) \mathrm{K}_{\mathrm{it}-1} / \mathrm{V}_{\mathrm{it}}-\mathrm{C}_{\mathrm{i}}^{\prime}\left(\mathrm{I}_{\mathrm{it}} / \mathrm{K}_{\mathrm{it}-1}\right) \mathrm{I}_{\mathrm{it}} / \mathrm{V}_{\mathrm{it}}\right) / \mathrm{Y}_{\mathrm{t}}\right] \mathrm{dk}_{\mathrm{i}}(\mathrm{t}-1)\right\}
\end{aligned}
$$

Equation (8) is only slightly different than the standard growth accounting formula in Solow (1957). The first two terms are standard, with the coefficients on hours growth in period t and capital stock growth in period t collapsing to the Cobb-Douglas parameters (and income shares) in the absence of adjustment costs. However, the subtle differences are important. First, the adjustment cost term associated with investment growth in asset $\mathrm{i}$ in (8) subtracts from income growth. Typically, such a term will be unimportant (because adjustment costs are small and the nominal investment share of asset $\mathrm{i}$ is small relative to the nominal capital share); however, for a new good (like computers), adjustment costs could be substantial and the nominal investment share may be close to the nominal capital share--implying the negative effect of adjustment costs at the end of (8) may be quantitatively important. The specification of adjustment costs also implies that lagged capital stock growth and the contemporaneous growth of technological change specific to investment goods also impact output growth. Ignoring all these effects assigns the impact of adjustment costs to the "residual"--commonly called labor-augmenting technological progress or multifactor productivity.

\section{"Long-run Growth Accounting”}

Long-run growth accounting will refer to the sources of growth along a steady-state path. The full specification of a steady-state growth path would require some discussion of consumer preferences and constraints, etc.--issues that are ancillary to the main objective of this paper. In order to most simply illustrate the impact of labor-augmenting technological progress and investment-good specific technological progress on output growth along a steady-state path, a simple modified-balanced growth path is assumed. In particular, our interest lies in a steady-state growth path with the following properties

- a constant nominal interest rate $r$ 
- $\quad$ stable growth in $\mathrm{Z}, \mathrm{E}$, and $\mathrm{V}_{\mathrm{i}}\left(\right.$ at rates $\left.\mathrm{g}_{\mathrm{z}}, \mathrm{g}_{\mathrm{e}}, \mathrm{g}_{\mathrm{i}}\right)$

- $\quad$ constant investment to capital stock ratios $\left(\mathrm{I}_{\mathrm{i}} / \mathrm{K}_{\mathrm{i}-1}\right)$

- $\quad$ constant nominal investment shares $\left(\mathrm{P}_{\mathrm{i}} \mathrm{I}_{\mathrm{i}} / \mathrm{PY}\right)$.

A constant nominal investment share (overall) is equivalent to assuming a constant savings rate (in a closed economy)--a common simplification when discussing growth outside of fully specified general equilibrium models.

Examination of (7) along a steady-state path with the properties noted above, given (6), implies that $\mathrm{K}_{\mathrm{i}} / \mathrm{Y}$ must grow along the steady state path at rate $\mathrm{g}_{\mathrm{i}}$ (i.e., the growth in technological change specific to good i). The steady-state production function can be written as

$$
\begin{aligned}
\mathrm{Y}_{\mathrm{t}} & =\mathrm{F}\left(\mathrm{K}_{1 \mathrm{t}}, \ldots, \mathrm{K}_{\mathrm{Nt}}, \mathrm{K}_{1 \mathrm{t}-1}, \mathrm{~V}_{1 \mathrm{t}}, \ldots, \mathrm{K}_{\mathrm{Nt}-1}, \mathrm{~V}_{\mathrm{Nt}} \mathrm{Z}_{\mathrm{t}} \mathrm{E}_{\mathrm{t}} \mathrm{H}_{\mathrm{t}}\right) \\
& =\left(\prod_{\mathrm{I}=1}{ }^{\mathrm{N}} \mathrm{K}_{\mathrm{it}}^{\mathrm{a} \_\mathrm{i}}\right)\left(\mathrm{Z}_{\mathrm{t}} \mathrm{E}_{\mathrm{t}} \mathrm{H}_{\mathrm{t}}\right)^{1-\mathrm{L}_{-} \mathrm{i}}-\sum_{\mathrm{I}=1}{ }^{\mathrm{N}} \mathrm{C}_{\mathrm{i}}\left(\mathrm{I}_{\mathrm{i}} / \mathrm{K}_{\mathrm{i}-1}\right) \mathrm{K}_{\mathrm{it}-1} / \mathrm{V}_{\mathrm{it}}
\end{aligned}
$$

where the constancy of $\mathrm{I}_{\mathrm{i}} / \mathrm{K}_{\mathrm{i}-1}$ along the growth path has been used. The production function in (9) is homogeneous of degree one in $\mathrm{K}_{1}, \ldots, \mathrm{K}_{\mathrm{Nt}}, \mathrm{K}_{1 \mathrm{t}-1}, \ldots, \mathrm{K}_{\mathrm{Nt}-1}, \mathrm{H}_{\mathrm{t}}$ and yields the following first-order approximation to growth along the steady-state path

$$
\begin{aligned}
\operatorname{dy}(\mathrm{t})= & \sum\left\{\left[\mathrm{F}_{\mathrm{Ki}} \mathrm{K}_{\mathrm{i}} / \mathrm{Y}\right] \mathrm{dk}_{\mathrm{i}}(\mathrm{t})\right\}+\left[\mathrm{F}_{\mathrm{H}} \mathrm{H} / \mathrm{Y}\right](\mathrm{dz}(\mathrm{t})+\mathrm{de}(\mathrm{t})+\mathrm{dh}(\mathrm{t}))+ \\
& \sum\left\{\left[\mathrm{F}_{\mathrm{Ki}[-1]} \mathrm{K}_{\mathrm{i}-1} / \mathrm{Y}\right]\left(\mathrm{dk}_{\mathrm{i}}(\mathrm{t}-1)-\mathrm{dv}_{\mathrm{i}}(\mathrm{t})\right)\right.
\end{aligned}
$$

where $\mathrm{F}_{\mathrm{Ki}[-1]} \mathrm{K}_{\mathrm{i}-1} / \mathrm{Y}=-\mathrm{F}_{\mathrm{vi}} \mathrm{V}_{\mathrm{i}} / \mathrm{Y}$ has been used. Rearranging this equation (and inserting the balanced growth conditions $\mathrm{dk}_{\mathrm{i}}(\mathrm{t}-1)-\mathrm{dv}_{\mathrm{i}}\{\mathrm{t})=\mathrm{g}_{\mathrm{y}}$ and $\mathrm{dk}_{\mathrm{i}}(\mathrm{t})=\mathrm{g}_{\mathrm{y}}+\mathrm{g}_{\mathrm{i}}$, where $\mathrm{g}_{\mathrm{y}}$ is the growth rate of output $^{5}$ ) yields the steady-state growth rate of output

$$
\mathrm{g}_{\mathrm{y}}=\mathrm{g}_{\mathrm{z}}+\mathrm{g}_{\mathrm{e}}+\mathrm{g}_{\mathrm{h}}+\left[\sum_{\mathrm{I}=1}{ }^{\mathrm{N}}\left\{\left[\mathrm{F}_{\mathrm{Ki}} \mathrm{K}_{\mathrm{i}} / \mathrm{Y}\right] \mathrm{g}_{\mathrm{i}}\right] /\left(1-\sum_{\mathrm{I}=1}{ }^{\mathrm{N}}\left[\mathrm{F}_{\mathrm{Ki}} \mathrm{K}_{\mathrm{i}} / \mathrm{Y}\right]-\sum_{\mathrm{I}=1}{ }^{\mathrm{N}}\left[\mathrm{F}_{\mathrm{Ki}[-1]} \mathrm{K}_{\mathrm{i}[-1]} / \mathrm{Y}\right]\right) .\right.
$$

Output growth equals the growth in labor-augmenting technological progress plus the growth in labor quality and hours, plus the contribution of technological change specific to investment good i. Note that the weight given to growth in technological change specific to investment good $\mathrm{i}\left(\left[\mathrm{F}_{\mathrm{Ki}} \mathrm{K}_{\mathrm{i}} / \mathrm{Y}\right] /\left(1-\sum_{\mathrm{I}=1}^{\mathrm{N}}\left[\mathrm{F}_{\mathrm{Ki}} \mathrm{K}_{\mathrm{i}} / \mathrm{Y}\right]-\sum_{\mathrm{I}=1}^{\mathrm{N}}\left[\mathrm{F}_{\mathrm{Ki}[-1]} \mathrm{K}_{\mathrm{i}[-1]} / \mathrm{Y}\right]\right)\right)$ exceeds the elasticity of output with respect to asset $\mathrm{i}$ in the production function $\left(\left[\mathrm{F}_{\mathrm{Ki}} \mathrm{K}_{\mathrm{i}} / \mathrm{Y}\right]\right)$ because technological change specific to investment good i increases investment in good $\mathrm{i}$ (due to the falling relative price) and investment in all other capital assets (because the additional investment in good $\mathrm{i}$ raises the

${ }^{5}$ These restrictions arise from the constancy of the nominal investment share of asset $i$ and the investment/lagged capital ratio. 
marginal product of other capital assets).

Equation (10) will provide the framework in which the long-run contribution of computers to economic growth is calculated; simply parameterize adjustment costs, use equations (6) and (7) and the relevant data to determine the growth rate of asset-specific technological change (using relative prices) and the Cobb-Douglas parameters, and then use equation (10) to calculate long-run contributions. This process differs from standard growth accounting practice because the presence of adjustment costs eliminates the equivalence between the Cobb-Douglas parameter and the capital income share of an asset. In particular, if a good is new, so I/K is high relative to the steady-state level and the marginal value of the good is above its purchase price (from (6)), then incorporation of adjustment costs will result in a higher CobbDouglas share for the new good when (7) is used to compute the share because Q lies above P; of course, this type of adjustment is exactly what is needed when considering the long-run impact of a new good, because the capital stock is below its desired level, implying that using observed prices and capital stocks to compute the Cobb-Douglas share of the new good yields an artificially low estimate of the share.

\section{Data}

The data used in this study cover the nonfarm business sector of the US economy--the sector of primary interest in the Bureau of Labor Statistics' multifactor productivity releases. The most recent BLS data cover the period 1948 to 1997; the data are extended through 1998 in the manner discussed below. The series for output (real and nominal), labor hours, and labor quality are taken directly from the BLS. The BLS growth accounting exercise for the nonfarm business sector considers 67 distinct capital assets (types of structures and equipment) plus several types of inventories and land; this paper ignores the contributions of inventories and land and focuses solely on the structure and equipment asset types. Data on the capital stock, investment, and price of each of the 67 capital assets are taken from the BLS. There are seven types of computer and peripheral equipment assets (mainframes, PCs, terminals, printers, direct access storage devices, tape drives, and storage devices), and references to "computers" below refer to the combination of these assets. 
Because the official BLS series only extend through 1997, values for 1998 were imputed. Both real and nominal nonfarm business output for 1998 were computed by growing the BLS series by the 1998 growth rate in the Bureau of Economic Analysis (BEA) measure of nonfarm output that are published with each quarterly NIPA report. Nonfarm business hours were extended with the corresponding series in the quarterly Productivity and Cost release. Labor quality, a relatively smooth series, was assumed to grow in 1998 by 0.3 percent, its average from 1955 to 1997 . The investment series for each of the 67 asset types were extended with growth rates of a corresponding series in the quarterly NIPA releases. In particular, each of the seven computer asset types was extended with the growth in the office and computing equipment component of producers durable equipment (PDE); trucks and automobiles were extended with the growth in motor vehicle PDE; communications equipment was extended with the growth in communications equipment PDE; all other equipment was extended with the growth in other PDE; the components of nonresidential and residential structures were extended with the most similar aggregate in the NIPA release. Price deflators for these aggregates in 1998 were extended similarly. The depreciation rate in (3) was determined by using the BLS series on capital stocks and investment to determine $\mathrm{d}_{\mathrm{i}}$; the 1998 values for capital stocks were found by using the imputed 1998 investment series and (3). In constructing the "user costs", the nominal interest rate (r) was set at $10 .^{6}$

Turning to adjustment costs, the calibrations below assume that adjustment costs are zero for all asset types except computers. This assumption was made because computers are the primary example of a relatively new good that constitutes an important fraction of investment; as discussed in section 6, incorporating adjustment costs for other goods does not have an important impact on any results. The data used in the calibration of the adjustment costs for computers comes from the Gartner Group (1999)--an information technology consulting firm. The Gartner Group conducted a survey of US businesses, nonprofit organizations, and federal and state and

${ }^{6}$ This value yields an overall income share of fixed capital of a little more than $1 / 5$ over the postwar period--close to the value in the BLS multifactor productivity release. Note that the overall capital income share in the BLS multifactor productivity calculations is closer to $1 / 3$, but this figure includes income from land and inventories, which are ignored in this study. 
local governments to determine the percentage of revenues allocated to information technology budgets overall, and the percentage allocated to information technology systems (i.e., hardware). According to this research, about 20 to 40 percent of total IT spending is systems spending (hardware), with the remainder allocated to training, support, and software; note that these other types of expenditures are costs of adjusting the stock of computing hardware. According to this metric, adjustment costs for computers are potentially one-and-a-half to four times the investment expenditure. This result is similar to Gurbaxani (1990), who found that hardware accounted for about 40 percent of the total cost of information systems over the 1976 to 1984 period.

In addition, the Gartner Group (1999) reports that IT budgets, including hardware expenses and adjustment costs, were 4.2 percent of total revenue in 1998 (about the same as 1997). In the alternative calibrations below, the adjustment cost parameters for computer asset types will be chosen such that the nominal share of computer investment expenditures and adjustment costs in nominal nonfarm business output (in the form of investment and foregone output, $\left.\mathrm{P}_{\mathrm{i}} \mathrm{I}_{\mathrm{i}}+\mathrm{PC}_{\mathrm{i}}\left(\mathrm{I}_{\mathrm{il}} / \mathrm{K}_{\mathrm{it}-1}\right) \mathrm{K}_{\mathrm{it}-1} / \mathrm{V}_{\mathrm{it}}\right)$ is 4.2 percent in 1998. In the three calibrations with positive adjustment costs for computers (labeled high, moderate, and low adjustment costs), the adjustment cost function takes the form

$$
\mathrm{C}_{\mathrm{i}}\left(\mathrm{I}_{\mathrm{it}} / \mathrm{K}_{\mathrm{it}-1}\right) \mathrm{K}_{\mathrm{it}-1} / \mathrm{V}_{\mathrm{it}}=0.5 \mathrm{c}_{\mathrm{i}}\left(\mathrm{I}_{\mathrm{it}} / \mathrm{K}_{\mathrm{it}-1}-\mathrm{X}_{\mathrm{i}}\right)^{2} \mathrm{~K}_{\mathrm{it}-1} / \mathrm{V}_{\mathrm{it}}
$$

where $c_{i}$ and $x_{i}$ are constants. ${ }^{7}$

- In the high adjustment cost calibration, steady-state adjustment costs equal zero, implying $x_{i}=d_{i}+g_{i}+g_{y}$ (where $g_{y}$ is the average growth rate of output; this value of $x_{i}$ takes into account replacement investment and normal steady-state growth in investment) and $\mathrm{c}_{\mathrm{i}}=$ 14.7.

- In the moderate adjustment cost calibration, replacement investment is assumed not to incur any adjustment costs, implying $\mathrm{x}_{\mathrm{i}}=\mathrm{d}_{\mathrm{i}}$ and $\mathrm{c}_{\mathrm{i}}=6.9$.

- In the low adjustment cost calibration, all investment incurs adjustment costs, implying $\mathrm{x}_{\mathrm{i}}$

${ }^{7}$ This form of adjustment cost function has been widely used in the empirical literature (see references below). Of course, this form should simply be viewed as a restricted secondorder approximation of a more general specification. 


$$
=0 \text { and } \mathrm{c}_{\mathrm{i}}=4.6 \text {. }
$$

In addition, a version of the model without adjustment costs for computers $\left(c_{i}=0\right)$ is considered to illustrate the effects of adjustment costs on both short and long-run growth accounting.

\section{Short-Run Growth Accounting}

Tables 1 to 4 provide the short-run growth decomposition (equation (8)) for the 4 calibrations--no adjustment costs, and high, moderate, and low adjustment costs. The following rearrangement of (8) is a useful guide to the tables:

$$
\begin{array}{rlr}
\mathrm{dy}(\mathrm{t})= & \left(1-\sum \mathrm{a} \_\mathrm{i}\right)\left[\left(\mathrm{Y}_{\mathrm{t}}+\sum_{\mathrm{I}=1}{ }^{\mathrm{N}} \mathrm{C}_{\mathrm{i}}\left(\mathrm{I}_{\mathrm{it}} / \mathrm{K}_{\mathrm{it}-1}\right) \mathrm{K}_{\mathrm{it}-1} / \mathrm{V}_{\mathrm{it}}\right) / \mathrm{Y}_{\mathrm{t}}\right] \mathrm{dz}(\mathrm{t})+ & \text { "Labor Augmenting } \\
& \left(1-\sum \mathrm{a} \_\mathrm{i}\right)\left[\left(\mathrm{Y}_{\mathrm{t}}+\sum_{\mathrm{I}=1}{ }^{\mathrm{N}} \mathrm{C}_{\mathrm{i}}\left(\mathrm{I}_{\mathrm{it}} / \mathrm{K}_{\mathrm{it}-1}\right) \mathrm{K}_{\mathrm{it}-1} / \mathrm{V}_{\mathrm{it}}\right) / \mathrm{Y}_{\mathrm{t}}\right] \mathrm{de}(\mathrm{t})+ & \text { "Labor Quality" } \\
& \left.\left(1-\sum \mathrm{a} \_\mathrm{i}\right)\left[\left(\mathrm{Y}_{\mathrm{t}}+\sum_{\mathrm{I}=1}{ }^{\mathrm{N}} \mathrm{C}_{\mathrm{i}}\left(\mathrm{I}_{\mathrm{it}} / \mathrm{K}_{\mathrm{it}-1}\right) \mathrm{K}_{\mathrm{it}-1} / \mathrm{V}_{\mathrm{it}}\right) / \mathrm{Y}_{\mathrm{t}}\right] \mathrm{dh}(\mathrm{t})\right)+ & \text { "Labor Hours" } \\
& \sum\left\{\left[\mathrm{a} \_\mathrm{i}\left(\mathrm{Y}_{\mathrm{t}}+\sum_{\mathrm{I}=1}{ }^{N} \mathrm{C}_{\mathrm{i}}\left(\mathrm{I}_{\mathrm{it}} / \mathrm{K}_{\mathrm{it}-1}\right) \mathrm{K}_{\mathrm{it}-1} / \mathrm{V}_{\mathrm{it}}\right) / \mathrm{Y}_{\mathrm{t}}\right] \mathrm{dk}_{\mathrm{i}}(\mathrm{t})\right\}- & \text { "Capital” } \\
& \sum\left\{\left[\left(\mathrm{C}_{\mathrm{i}}^{\prime}\left(\mathrm{I}_{\mathrm{it}} / \mathrm{K}_{\mathrm{it}-1}\right) \mathrm{I}_{\mathrm{it}} / \mathrm{V}_{\mathrm{it}}\right) / \mathrm{Y}_{\mathrm{t}}\right] \mathrm{di}_{\mathrm{i}}(\mathrm{t})\right\}+ \\
& \sum\left\{\left[\left(\mathrm{C}_{\mathrm{i}}\left(\mathrm{I}_{\mathrm{it}} / \mathrm{K}_{\mathrm{it}-1}\right) \mathrm{K}_{\mathrm{it}-1} / \mathrm{V}_{\mathrm{it}}\right) / \mathrm{Y}_{\mathrm{t}}\right] \mathrm{d} \mathrm{d}_{\mathrm{i}}(\mathrm{t})\right\}- \\
& \sum\left\{\left[\left(\mathrm{C}_{\mathrm{i}}\left(\mathrm{I}_{\mathrm{it}} / \mathrm{K}_{\mathrm{it}-\mathrm{t}}\right) \mathrm{K}_{\mathrm{it}-1} / \mathrm{V}_{\mathrm{it}}-\mathrm{C}_{\mathrm{i}}^{\prime}\left(\mathrm{I}_{\mathrm{it}} / \mathrm{K}_{\mathrm{it}-1}\right) \mathrm{I}_{\mathrm{it}} / \mathrm{V}_{\mathrm{it}}\right) / \mathrm{Y}_{\mathrm{t}}\right] \mathrm{dk}_{\mathrm{i}}(\mathrm{t}-1)\right\}
\end{array}
$$

Note that the tables provide average contributions to growth for three periods: 1955-73, 1974-84, and 1985-1998. The periods were chosen both to represent major shifts in the importance of computers for the economy and to provide some perspective on how computers relate to the post73 productivity slowdown. More specifically, investment in mainframe computers enters the BLS productivity data in 1966 and becomes important by the early 1970s, and investment in PCs enter the BLS productivity data in 1982 and takes off shortly thereafter. ${ }^{8}$

The results with no adjustment costs are familiar from both the BLS multifactor productivity release and the large body of research on output growth that follows the growth accounting framework introduced by Solow (1957). In particular, output growth slowed markedly after 1973, with most of the slowdown concentrated in the contribution from laboraugmenting technological progress (or "multifactor productivity"). The importance of computers

\footnotetext{
${ }^{8}$ Mainframe computers obviously were around for a couple of decades before mass business applications developed; the IBM PC was introduced in 1981.
} 
for output growth has risen dramatically--from a contribution of essentially zero before 1974 to near $1 / 4$ percentage point over the most recent 14 years. However, the magnitude of the contribution of computers is small relative to the productivity slowdown, largely because computers are a small share of the aggregate capital stock. These results are by now well-known, following Oliner and Sichel (1994), Gordon (1998), Sichel (1999), and Jorgenson and Stiroh (1999), among others. ${ }^{9}$

The results with adjustment costs for computers are quite different. Focusing first on the results describing the contribution of labor-augmenting technological progress to output growth, tables 2 to 4 find that the contribution of labor-augmenting technological progress has been higher--by 0.4 to 0.5 percentage point--since 1973 than under the no adjustment cost case. This result occurs because the introduction of computers causes large adjustment costs--line 5--in these calibrations. Note that the contribution of labor-augmenting technological progress is equivalent to growth in multifactor productivity as typically defined. The cases with adjustment costs therefore find a smaller slowdown in multifactor productivity after 1973 than an analysis that does not consider adjustment costs. All three cases with adjustment costs indicate that the contribution of computers to output growth has been negative--as the adjustment costs outweighed the productive impact of computer investment. Of course, this conclusion does not suggest that firms' decision to invest in computers was mistaken; rather, the analysis reveals that the substantial "reorganization" of business activity stemming from the computer revolution has been associated with large costs that optimizing firms expect to recoup in the future.

Simply put, previous work has attributed much of the slowdown in labor productivity growth to a slowdown in technological progress, but a combination of adjustment costs and the explosion in computer investment suggests a significant role of the IT revolution as a drag on output growth in recent decades. This drag on growth from computers occurs because changing business practices to utilize computers--or adjusting to the new investment--is costly.

Why have computers been such a drag on output growth in a growth accounting exercise

${ }^{9}$ Oliner and Sichel $(1994)$ and Sichel $(1997,1999)$ focus on the nonfarm business sector and hence present results most similar to those in table 1; Jorgenson and Stiroh (1999) focus on a more comprehensive measure of output. 
with adjustment costs? A particular focus on PCs proves useful. Table 5 presents the growth rate of investment in PCs, the rate of increase in the relative price of PCs (which is the inverse of the rate of PC-specific technological change), and the investment to capital stock (lagged) ratio. Remember that along the balanced-growth path, the investment to capital stock (lagged) ratio equals replacement investment plus investment spurred by computer-specific technological progress plus investment spurred by overall output growth $\left(\mathrm{d}_{\mathrm{i}}+\mathrm{g}_{\mathrm{i}}+\mathrm{g}_{\mathrm{y}}\right.$; this is the sum of lines 2,3, and 4). As is clear from the table, PCs are nowhere near this predicted steady-state growth path and are still in a ramp-up period over 1985-1998. This example illustrates how applying standard growth accounting practices when adjustment costs are important provides a misleading picture of labor-augmenting technological progress.

\section{Long-run Growth Accounting}

Tables 6-9 implement the long-run growth accounting decomposition contained in (10):

$$
\mathrm{g}_{\mathrm{y}}=\mathrm{g}_{\mathrm{z}}+\mathrm{g}_{\mathrm{e}}+\mathrm{g}_{\mathrm{h}}+\left[\sum_{\mathrm{I}=1} \mathrm{~N}\left\{\left[\mathrm{~F}_{\mathrm{Ki}} \mathrm{K}_{\mathrm{i}} / \mathrm{Y}\right] \mathrm{g}_{\mathrm{i}}\right] /\left(1-\sum_{\mathrm{I}=1}{ }^{\mathrm{N}}\left[\mathrm{F}_{\mathrm{Ki}} \mathrm{K}_{\mathrm{i}} / \mathrm{Y}\right]-\sum_{\mathrm{I}=1}{ }^{\mathrm{N}}\left[\mathrm{F}_{\mathrm{Ki}[-1]} \mathrm{K}_{\mathrm{i}[-1]} / \mathrm{Y}\right]\right) .\right.
$$

The trend growth rate for hours $\left(\mathrm{g}_{\mathrm{h}}=1.1\right.$ percent) is taken from the Congressional Budget Office (1999) and is based largely on medium-term population demographics. The trend growth rate of labor quality, which depends on education and experience of the workforce, is set at $\mathrm{g}_{\mathrm{e}}=0.3$ percent--the average from 1955 to 1997 and a bit below recent experience. Neither of these estimates is derived from the framework developed in this paper. For trend growth in laboraugmenting technological progress $\left(\mathrm{g}_{\mathrm{z}}\right)$, the average growth rate of the series (measured with any modifications necessary to account of adjustment costs) from 1974 to 1998 is used. ${ }^{10}$ For the trend growth of investment-good specific technological progress $\left(\mathrm{g}_{\mathrm{i}}\right)$, the average rate of decline (inverse of rate of increase) of the relative price of the good over the maximum available time period in the BLS data is used. Note that using the historical average of price declines as a

${ }^{10}$ As shown in (8), the short-run contribution of labor-augmenting technological progress does not include the capital accumulation spurred by this progress and hence labor augmenting technological progress is multiplied by $\left(1-\sum \mathrm{a} \_\mathrm{i}\right)$ to determine its short-run contribution. The long-run contribution does account for the capital accumulation caused by technological progress, and hence does not multiply by $\left(1-\sum \mathrm{a} \_\mathrm{i}\right)$. This accounts for the numerical difference in the short-run and long-run contribution tables. 
measure of the trend in investment-good specific technological progress assumes that computer prices, for example, will continue to fall rapidly (i.e., that Moore's law does not unravel).

Finally, the income-share terms that feed into the terms containing investment-specific technological progress are the averages over 1985-1998.

Table 6 provides the no-adjustment cost forecast; as shown in line 6, output growth is expected to lie near 2.1 percent, with computers contributing near 1/4 percentage point to longrun growth. This type of forecast is not particularly optimistic--for example, this forecast for output growth is more than $1 / 2$ percentage point lower than any of the time periods shown in tables 1-4. In part, this is because hours growth is expected to be weak; growth in output per hour (line 6 minus line 1) is expected to be 1 percent per year, which is the average from 19741991 (i.e., in the most recent period excluding the current, incomplete expansion). The main factor leading to sluggish growth is the weak performance of labor-augmenting technological progress in recent decades. Note that this sort of pessimistic scenario regarding output growth is the typical result of growth-accounting forecasts, including those that focus on computers; two examples are the comment from Gordon (1998) highlighted in the introduction and the forecasts contained in Oliner and Sichel (1994).

Tables 7-9 are much more optimistic about the prospects for output growth--largely because of a more optimistic view regarding future growth in labor-augmenting technological progress and the contribution of computers to output growth. Under each calibration of adjustment costs, growth in labor-augmenting technological progress since 1974 has been much stronger (0.4-0.6 percentage point stronger) than measured in the absence of adjustment costs, and the continuation of this pace of technological progress boosts output growth. In addition, computer-specific technological progress is expected to boost output growth about 0.5 percentage points. Combining these effects suggests trend output growth near 2.9 percent, about 3/4 percentage point stronger than suggested when adjustment costs are ignored. In these cases, output per hour is expected to grow about 1.8 percent per year (line 6 minus line 1), implying a doubling of output per hour every 39 years (as compared to the 69 years required for output per hour to double when growing at 1 percent per year). 


\section{How Big Are Adjustment Costs?}

The growth accounting exercises performed in the previous section suggest that the incorporation of adjustment costs has a quantitatively important effect on measured laboraugmenting technological progress. Of course, this is to be expected when very large adjustment costs are used in the calculations. However, the available empirical evidence does not suggest that the adjustment costs employed in this study are too large.

- $\quad$ The adjustment costs are parameterized to match the available data on the total costs of installing new computer systems (from the Gartner Group (1999) and Gurbaxani (1990)).

- $\quad$ The low and moderate adjustment cost calibrations use values of $c_{i}$ within the range reported in recent studies that estimate adjustment costs for equipment and structures (such as Barnett and Sakellaris (1997). These values for $c_{i}$ are much lower than those traditionally estimated in the investment literature (such as Summers (1981), who reports a value of $c_{i}$ double the value used in the high adjustment cost specification). The literature summarized in Chirinko (1993) reports much higher adjustment costs.

- $\quad$ One previous study uses firm level data on capital stocks by asset class (including computers) and stock market values in order to generate estimates of how the market values a marginal unit of different assets (Brynjolfsson and Yang (1998)). Over the 1986-1994 period, this study reports that a dollar of computer investment is valued at between $\$ 5$ and $\$ 20$ by the market. ${ }^{11}$ The corresponding data series in this paper is the marginal value of computers ( $\mathrm{Q}$ for computers)--which is graphed in figure $1 .^{12}$ In all three cases, the average Q over 1986-1994 is about 4-1/2--in range of the Brynjolfsson and Yang (1998) estimates.

This other evidence suggests that the range of adjustment costs considered in sections 4 and 5 is reasonable.

One set of estimates of adjustment costs--reported in Hassett and Hubbard (1996)--are a

${ }^{11}$ The $\$ 5$ figure refers to the reported within-firm estimates (i.e., controlling for firmlevel fixed effects) while the $\$ 20$ figure refers to the between-firm estimates.

${ }^{12}$ The $\mathrm{Q}$ data are the weighted average over the 7 types of computer assets, where the weights are nominal investment shares. 
bit lower than those used in this study, with $\mathrm{c}_{\mathrm{i}}$ near 2 . However, these estimates are low relative to most others, and refer to all equipment and structures rather than just computers. Given that computers are a new technology, with significant levels of business investment only beginning in the late 1960s and the PC appearing in the early 1980s, higher adjustment costs for computers may be reasonable.

In fact, the levels of adjustment costs assumed in this study are not large relative to some other recent research, summarized in Greenwood and Jovanovic (1998), that pursues a complementary approach to the impact of computers on economic growth. This research stresses the learning requirements and diffusion lags inherent in the adoption of any new technology, and suggests that recent decades have been ones in which the learning process associated with the introduction of computers has held down output growth. ${ }^{13}$ Once the learning process is complete, output growth will pick up. Overall, the "story" in this alternative approach is very similar; as shown above, incorporation of a standard form of investment adjustment costs in the net production function reveals that these costs associated with computers have held down output growth (and hence measured growth in labor-augmenting technological progress) and that future output growth will be faster. However, the types of models summarized in Greenwood and Jovanovic (1998) are quite complicated--requiring estimates of the learning and diffusion processes for new technologies. While some progress in these areas has been made, by-and-large the available evidence is more descriptive than quantitative (for example, David $(1990,1999)$ ). The evidence on learning and diffusion that is available suggests a wide range of such costs (Gort and Klepper (1982)) and provides little guidance on the magnitude of such costs for computers.

A final point on adjustment costs is the focus on computers as the investment good for which adjustment costs are important. The investment experience for computers in recent decades has been quite different than that of any other good--because computers are so new and have grown so rapidly to become one of the largest asset classes (in nominal terms). Table 10 illustrates this point by allowing there to be adjustment costs on all assets; the results in table 10 assume all assets face adjustment costs that correspond to the low adjustment cost calibration

\footnotetext{
${ }^{13}$ Also see Greenwood and Yorukoglu (1997) and Kiley (1999).
} 
introduced in section 3. As shown in the last two columns, allowing adjustment costs on capital assets excluding computers (line 4) has only small effects on the contributions of capital excluding computers to output growth or on the measurement of labor augmenting technological progress in recent decades (compare to table 4). This example illustrates how the computer revolution really is quite different from the investment experience of any other asset in the recent period. In other words, while incorporation of adjustment costs into growth accounting was not necessary when Solow (1957) introduced the standard framework, incorporation of such costs is quantitatively important in recent decades because of computers.

\section{Summary}

Investment in computers by the US nonfarm business sector has been substantial; PCs did not even exist as a business asset class until the 1980s, and by 1997 nominal investment in PCs was larger than that in all other equipment and structure asset classes defined by the BLS except communications equipment and trucks. This revolution in business practice can be expected to have large transitional costs.

The traditional approach to growth accounting--introduced in Solow (1957)--assumes that the economy is near a steady-state growth path where investment adjustment costs are not important. Incorporating reasonable levels of transitional costs for computers--in the form of investment adjustment costs as specified in a voluminous empirical literature--reveals that these costs have an important impact on growth-accounting. Typical growth accounting exercises ignore such costs and have hence overstated the decline in the growth rate of labor-augmenting technological progress since 1974 (probably by near $1 \frac{2}{2}$ percentage point per year). In addition, previous investigations of the impact of computers in a growth accounting framework have valued computer investment at its purchase price--whereas incorporation of adjustment costs imply that the marginal value of a computer lies above its purchase price. Considering this effect raises the estimate of the likely long-run contribution of computers to economic growth. Combining the effects on measurement of labor-augmenting technological progress and the contribution of computers suggests a more optimistic future--with output growth near 2.9 percent rather than the 2 percent growth rate suggested by traditional growth accounting. 


\section{References}

Barnett, Steven A., and Plutarchos Sakellaris (1997) Nonlinear Response of Firm Investment to Q: Testing a Model of Convex and Non-convex Adjustment Costs. Journal of Monetary Economics 42(2):261-88.

Brynjolfsson, Erik, and Shinkyu Yang (1998) The Intangible Costs and Benefits of Computer Investments: Evidence from Financial Markets. Revised from Proceedings of the International Conference on Information Systems (December 1997).

Caballero, Ricardo (1997) Aggregate Investment. NBER Working Paper 6264.

Chirinko, Robert S. (1993) Business Fixed Investment Spending: A Critical Survey of Modeling Strategies, Empirical Results, and Policy Implications. Journal of Economic Literature 31:1875-1911.

Congressional Budget Office (1999) The Economic and Budget Outlook: Fiscal Years 20002009. July.

David, Paul A. (1990) The Dynamo and the Computer: An Historical Perspective on the Modern Productivity Paradox. American Economic Review Papers and Proceedings 355-361.

David, Paul A. (1999) Digital Technology and the Productivity Paradox: After Ten Years, What Has Been Learned? Presented at the Conference "Understanding the Digital Economy: Data, Tools and Research” US Dept. Of Commerce, May 25-26, 1999.

Dixit, Avinash, and Robert Pindyck (1994) Investment Under Uncertainty. Princeton University Press.

Eisner, Robert, and Robert H. Strotz (1963) Determinants of Business Investment. In Commission on Money and Credit: Impacts of Monetary Policy. Prentice Hall.

The Gartner Group (1999) Spending Levels Do Not Indicate Business Value. January 27, 1999

Gordon, Robert J. (1998) Monetary Policy in an Age of Information Technology: Computers and the Solow Paradox. Mimeo. June.

Gort, Michael, and S. Klepper (1982) Time Paths in the Diffusion of Product Innovations. Economic Journal 92:630-653.

Greenspan, Alan (1999) High-Tech Industry in the US Economy. Testimony before the Joint Economic Committee, United States Congress. June 14, 1999. 
Greenwood, Jeremy, and Boyan Jovanovic (1998) Accounting for Growth. NBER Working Paper 6647.

Greenwood, Jeremy and Mehmet Yorukoglu (1997) '1974.' Carnegie Rochester Conference Series on Public Policy, vol. 46 (June), pp. 49-96.

Gurbaxani, Vijay C. (1990) Managing Information Systems Costs: An Economic Analysis of the Hardware/Software Trade-offs. International Center for Information Technologies.

Hayashi, Fumio (1982) Tobin’s Marginal and Average q: A Neoclassical Interpretation. Econometrica 50:213-224.

Hassett, Kevin A., and R. Glenn Hubbard (1996) Tax Policy and Investment. NBER Working Paper 5683.

Jorgenson, Dale W. (1963) Capital Theory and Investment Behavior. American Economic Review 53:247-259.

Jorgenson, Dale W., and Kevin J. Stiroh (1999) Information Technology and Growth. American Economic Review Papers and Proceedings 109-115.

Kiley, Michael T. (1999) The Supply of Skilled Labour and Skill-Biased Technological Progress. Economic Journal 109:1-17.

Lucas, Robert E. (1967) Adjustment Costs and the Theory of Supply. Journal of Political Economy 75:321-334.

Oliner, Steven D., and Daniel E. Sichel (1994) Computers and Output Growth Revisited: How Big is the Puzzle? Brooking Papers on Economic Activity 2:273-334.

Sichel, Daniel E. (1997) The Computer Revolution. Brookings Institution.

Sichel, Daniel E. (1999) Computers and Economic Growth: An Update. Business Economics.

Solow, Robert (1957) Technical Change and the Aggregate Production Function. Review of Economics and Statistics 39:312-330.

Summers, Lawrence H. (1981) Taxation and Corporate Investment: A q-Theory Approach. Brookings Papers on Economic Activity 1:67-127.

Tobin, James (1969) A General Equilibrium Approach to Monetary Theory. Journal of Money, Credit, and Banking 1:15-29. 
Table 1: Contributions to Output: No Adjustment Costs

\begin{tabular}{|c|c|c|c|c|}
\hline & & \multicolumn{3}{|c|}{ Long-term trends } \\
\hline & & $1955-73$ & $1974-84$ & $1985-98$ \\
\hline & Output & 4.20 & 2.65 & 2.98 \\
\hline 2 . & Labor Hours & 1.23 & 1.30 & 1.44 \\
\hline 3. & Labor Quality & 0.12 & 0.19 & 0.38 \\
\hline 4. & Capital ex. computers & 0.59 & 0.55 & 0.55 \\
\hline 5 . & Computers & 0.03 & 0.16 & 0.23 \\
\hline 6. & Lab. Aug. Tec. Prog. & 2.22 & 0.44 & 0.37 \\
\hline
\end{tabular}

Table 2: Contributions to Output: High Adj. Costs

\begin{tabular}{|c|c|c|c|c|}
\hline & & \multicolumn{3}{|c|}{ Long-term trends } \\
\hline & & $1955-73$ & $1974-84$ & $1985-98$ \\
\hline & Output & 4.20 & 2.65 & 2.98 \\
\hline 2 . & Labor Hours & 1.24 & 1.32 & 1.48 \\
\hline 3. & Labor Quality & 0.12 & 0.19 & 0.40 \\
\hline 4 . & Capital ex. computers & 0.54 & 0.50 & 0.50 \\
\hline 5 . & Computers & 0.15 & -0.26 & -0.14 \\
\hline 6 . & Lab. Aug. Tec. Prog. & 2.14 & 0.89 & 0.74 \\
\hline
\end{tabular}


Table 3: Contributions to Output: Moderate Adj. Costs

\begin{tabular}{|c|c|c|c|c|}
\hline & & \multicolumn{3}{|c|}{ Long-term trends } \\
\hline & & $1955-73$ & $1974-84$ & $1985-98$ \\
\hline & Output & 4.20 & 2.65 & 2.98 \\
\hline 2. & Labor Hours & 1.25 & 1.33 & 1.49 \\
\hline 3. & Labor Quality & 0.12 & 0.20 & 0.40 \\
\hline 4. & Capital ex. computers & 0.54 & 0.50 & 0.50 \\
\hline 5. & Computers & 0.06 & -0.34 & -0.27 \\
\hline 6. & Lab. Aug. Tec. Prog. & 2.23 & 0.96 & 0.86 \\
\hline
\end{tabular}

Table 4: Contributions to Output: Low Adj. Costs

\begin{tabular}{|c|c|c|c|c|}
\hline & & \multicolumn{3}{|c|}{ Long-term trends } \\
\hline & & $1955-73$ & $1974-84$ & $1985-98$ \\
\hline 1 . & Output & 4.20 & 2.65 & 2.98 \\
\hline 2. & Labor Hours & 1.25 & 1.33 & 1.49 \\
\hline 3 . & Labor Quality & 0.12 & 0.20 & 0.40 \\
\hline 4. & Capital ex. computers & 0.54 & 0.50 & 0.50 \\
\hline 5 . & Computers & 0.03 & -0.36 & -0.29 \\
\hline 6 . & Lab. Aug. Tec. Prog. & 2.25 & 0.98 & 0.87 \\
\hline
\end{tabular}


Table 5: Recent Behavior of PCs

\begin{tabular}{llrrr}
\hline & & $1985-89$ & $1990-94$ & $1995-98$ \\
\hline 1. Investment Growth (\%) & 25.48 & 33.87 & 45.68 \\
2. Relative Price Change (\%) & -15.74 & -23.02 & -33.46 \\
3. Depreciation Rate (\%) & 11.00 & 13.19 & 11.74 \\
4. I/K[lagged] ratio (\%) & 68.61 & 60.38 & 85.46 \\
\hline 5. Memo: NFB Output Growth (\%) & 3.43 & 1.74 & 3.97 \\
\hline
\end{tabular}


Table 6: Long-Run Growth in Output: No Adjustment Costs

Forecast

$\begin{array}{lr}\text { 1. Labor Hours } & 1.10 \\ \text { 2. Labor Quality } & 0.30 \\ \text { 3. Capital ex. computers } & -0.03 \\ \text { 4. Computers } & 0.24 \\ \text { 5. Lab. Aug. Tec. Prog. } & 0.50 \\ \text { 6. Output } & 2.12\end{array}$

Table 7: Long-Run Growth in Output: High Adjustment Costs

Forecast

1. Labor Hours

1.10

2. Labor Quality

0.30

3. Capital ex. computers

$-0.02$

4. Computers

0.53

5. Lab. Aug. Tec. Prog.

0.95

6. Output

2.85 
Table 8: Long-Run Growth in Output: Moderate Adjustment Costs

Forecast
1. Labor Hours
1.10
2. Labor Quality
0.30
3. Capital ex. computers
$-0.02$
4. Computers
0.46
5. Lab. Aug. Tec. Prog.
1.08
6. Output
2.92

Table 9: Long-Run Growth in Output: Low Adjustment Costs

\section{Forecast}

1. Labor Hours

2. Labor Quality

3. Capital ex. computers

4. Computers

5. Lab. Aug. Tec. Prog.

6. Output
1.10
0.30
$-0.02$
0.44
1.11
2.93 
Table 10: Contributions to Output: Low Adj. Costs Everywhere

\begin{tabular}{lllll}
\hline & & \multicolumn{3}{c}{ Long-term trends } \\
\cline { 3 - 5 } & & $1955-73$ & $1974-84$ & $1985-98$ \\
\hline 1. Output & 4.20 & 2.65 & 2.98 \\
2. Labor Hours & 1.25 & 1.39 & 1.46 \\
3. Labor Quality & 0.11 & 0.18 & 0.38 \\
4. Capital ex. computers & 0.39 & 0.57 & 0.53 \\
5. Computers & 0.03 & -0.36 & -0.29 \\
6. Lab. Aug. Tec. Prog. & 2.41 & 0.87 & 0.88 \\
& & & & \\
\hline
\end{tabular}




\section{Figure 1: Q for Computers}

High (Dashed Line)

Moderate (Solid Line)

Low (Dotted Line)

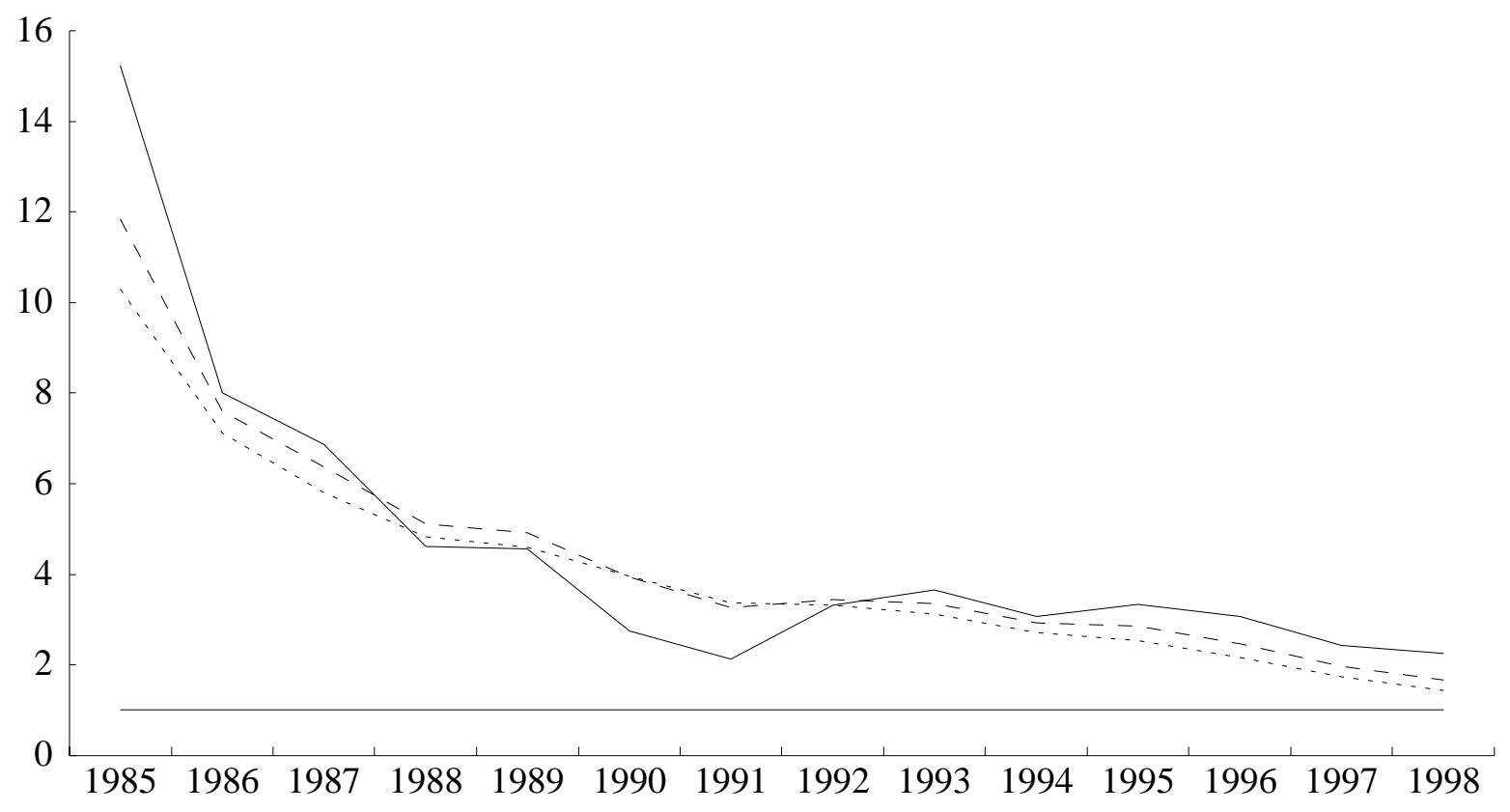

